\title{
SPONTANEOUS PNEUMOTHORAX AND PNEUMOMEDIASTINUM IN PREGNANCY
}

\author{
Sevdegul KARADAS ${ }^{1}$, Ayse Guler OKYAY ${ }^{2}$, Dolunay ODABASI ${ }^{3}$, Fatih SELVI ${ }^{2}$ \\ 1 Deparment of Emergency Medicine, Yuzuncu Yil University School of Medicine, Van, Turkey \\ 2 Department of Obstetrics and Gynecology, Mustafa Kemal University School of Medicine, Hatay, Turkey \\ 3 Department of Cardiovascular Surgery, Yuzuncu Yil University School of Medicine, Van, Turkey
}

\begin{abstract}
SUMMARY
Spontaneous acute pneumothorax may occur as a result of spontanous rupture of subpleural blebs or bullae and it is extremely rare during pregnancy. Spontaneous acute pneumothorax and pneumomediastinum were diagnosed in a young pregnant woman admitted with the complaints of swelling and pain on her neck and upper thorax following 2 days' dyspnea. Nasal oxygen, analgesics and antiemetics were used as needed during ten days' hospitalisation. Physical findings, chest X-ray and oxygen saturation improved at the end of this period. Since supportive treatment was sufficient, invasive treatments such as surgery or thorax tube were not required. Although rare, pneumothoax should be remembered in any pregnant woman with dyspnea and chest-pain and must be confirmed radiographically to distinguish it from other diseases and conditions. In this report, a case of spontaneous acute pneumothorax and pneumomediastinum in a 10 week primigravida is presented.
\end{abstract}

Key words: pneumomediastinum, pneumothorax, pregnancy

Journal of Turkish Society of Obstetrics and Gynecology, (J Turk Soc Obstet Gynecol), 2014; Vol: 11, Issue: Pages:

\section{GEBELİKTE SPONTAN PNÖMOTORAKS VE PNÖMOMEDİASTINUM}

\section{ÖZET}

Spontan akut pnömotoraks subplevral bleb veya büllerin spontan rüptürü sonucu gelişebilen ve gebelikte son derece nadir görülen bir durumdur. İki günlük dispneyi takiben toraks üst kısımlarda ve boyunda gelişen ağrı ve şişlik şikayeti ile başvuran genç bir gebede bilateral pnömotoraks ve pnömomediastinum teşhis edildi. Tedavide on günlük hospitalizasyon süresince gerek duyuldukça nazal oksijen, analjezikler ve antiemetikler kullanıldı. Bu süre sonunda, fizik muayene bulgularl, akciğer filmi ve oksijen saturasyonunda iyileşme kaydedildi. Destekleyici tedaviler yeterli olduğundan cerrahi ya da toraks tüpü gibi invaziv tedavilere gerek duyulmadı. Nadir görülmesine rağmen, dispne ve göğ̈̈s ă̆rısı şikayeti olan her gebede pnömotoraks akla getirilmeli ve diğer durumlardan ayırt etmek için tanı radyografik olarak doğrulanmalıdır. Bu makalede, 10 haftalık primigravid gebede spontan akut pnömotoraks ve pnömomediastinum olgusu sunulmuştur.

Anahtar kelimeler: gebelik, pnömomediastinum, pnömotoraks

Türk Jinekoloji ve Obstetrik Derneği Dergisi, (J Turk Soc Obstet Gynecol), 2014; Cilt: 11, Sayl: Sayfa:

Address for Correspondence: Dr. Ayşe Güler Okyay. Mustafa Kemal Üniversitesi Tıp Fakültesi, Kadın Hastalıkları ve Doğum Anabilim Dalı, Hatay Phone: +90 (533) 3347104 e-mail: doctorayseguler@yahoo.com.tr Received: 16 September 2013, revised: 10 October 2013, accepted: 12 October 2013, online publication: 


\section{INTRODUCTION}

Spontaneous acute pneumothorax may occur as a result of spontaneous rupture of subpleural blebs or bullae in a patient with otherwise healthy lungs ${ }^{(1,2)}$. It is extremely rare during pregnancy and potentially serious for both mother and fetus $(3,4)$. Diagnosis, treatment, follow-up of pregnancy and also the timing and mode of delivery are all problems related to this disease. In this report, we presented a case of acute pneumothorax and pneumomediastinum in a primigravida at 10 weeks of gestation.

\section{CASE}

A 22-years-old gravida 1, para 0 woman presented at 10th gestational week to the emergency department with the complaint of chest pain and swelling on her neck and upper thorax following 2 days' shortness of breath. She was also suffering from nausea and vomiting almost 6-7 times a day for 2 weeks resulting from hyperemesis gravidarum. She had no history of cough, fever, chills or trauma. She was a non-smoker with no history of pulmonary disease. Her medical history was unremarkable. She had no family history of pulmonary disease. On physical examination, she was found to be mildly tachypneic and her breath sounds were normal. Blood pressure was 100/60 $\mathrm{mmHg}$, pulse rate was 96 beats per minute, respiratory rate was 30 breaths per minute and temperature was $37.3^{\circ} \mathrm{C}$. Blood gas analysis confirmed normal arterial oxygen and carbon dioxide tension. On palpation, subcutaneous crepitation was noted over the neck. Liver enzymes were mildly elevated. Computed tomography (CT) of the chest revealing bilateral pneumothorax and pneumomediastinum was performed with abdominal shield. Also, subcutaneous emphysema in neck, upper thoracal and bilateral axillary skin areas were present on CT sections (Fig 1). Nasal oxygen was applied at a rate of 5-6 1t/min during 10 days' hospitalisation. Analgesics and antiemetics were used as needed. In order to exclude any esophageal rupture suspected, upper gastrointestinal system endoscopic examination was carried out immediately after the patient's condition was stabilized. Since physical findings, daily chest xrays and oxygen saturation were all improved day by day. Surgical treatment or thorax tube was not required and only supportive treatment was sufficient. The patient recovered well and was discharged on the tenth day. She and her family were advised about her condition and also the risk of recurrence. Therefore they were noted about the importance of regular followups. The patient had elective cesarean delivery because of cephalopelvic disproportion at another hospital at $38^{\text {th }}$ week under spinal anesthesia and gave birth to a healthy male baby. No recurrence of pneumothorax has occurred throughout the gestation.

Figure 1: Pneumomediastinum and bilateral pneumothorax seen in CT section.

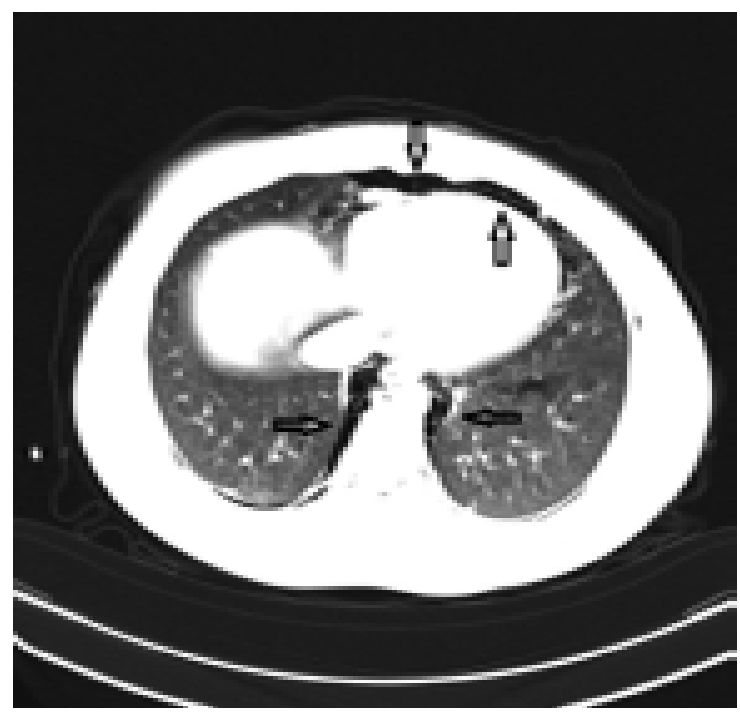

\section{DISCUSSION}

Spontaneous pneumothorax in pregnancy is extremely rare. Rupture of a subpleural apical bulla or bleb, pulmonary lymphangiomatosis and cavitary tuberculosis are the most common causes of spontaneous pneumothorax in pregnancy $(3,4)$. No history of pulmonary lymphangiomatosis or tuberculosis was noted in our patient. Spontaneous pneumothorax occurred during the perinatal period in $53.3 \%$ and during the first or second trimester in $46.7 \%$ of cases $(3)$. According to the review of 45 cases, the patients were young (average age $26.7 \pm 2.3$ ) and of low gravidity (mean gravidity 1.7$)^{(3,4)}$. Our patient was also quite young and it was her first pregnancy. Spontaneous pneumothorax occurred at very early stage of her gestation.

Our patient presented with chest pain, sweling in neck and dyspnea and she was referred to our university 
from a town hospital. According to previous reports the most common presenting symptoms of spontaneous pneumothorax in pregnancy were chest pain and dyspnea $^{(3,4)}$. Since she was in the first trimester of pregnancy, chest X-ray had been avoided there. However, chest radiographs are necessary to confirm the diagnosis and the potential risk and benefits associated with a radiologic examination must be compared. Ionizing radiation represents a potential risk to the fetus, particularly during the first 8 weeks of development, that is, the period of organogenesis. Therefore abdomen should be shielded during any radiographic examination. For standard chest radiography with a shielded maternal abdomen, the dose to the uterus is estimated to be $1 \mathrm{mrad}$ per examination. A single series of chest CT scans at $1 \mathrm{~cm}$ intervals exposes the conceptus to an uper limit of less than $1 \mathrm{rad}$, and the actual dose is likely closer to 0.5 $\operatorname{rad}^{(5)}$. No increased rates of anomalies have been reported in children exposed to less than $1 \mathrm{rad}$ of ionizing radiation in utero ${ }^{(5)}$. So, it is safe to perform the standard chest radiography when pneumothorax is suspected in a pregnant patient, even during the first trimester, if the abdomen is shielded ${ }^{(6)}$. Shielded computed tomography of thorax was taken right away in our emergency service.

A spontaneous pneumothorax should be considered in the differential diagnosis of chest pain and breathlessness during pregnancy and delivery. The differential diagnosis includes cardiac tamponade, pericarditis, angina pectoris, dissecting aneurysm, mediastinitis, pulmonary embolism and oesophageal tear ${ }^{(7)}$. A high index of suspicion is necessary to make the diagnosis and initiate the treatment. In our case, the diagnosis was easily made by CT scan of thorax. Actually standard chest radiography is diagnostic and should be the first step in diagnosis(7).

An underlying infection, asthma history of pneumothorax and cocaine use were considered as risk factors for spontaneous pneumothorax ${ }^{(8)}$. But interestingly, our patient had none of the mentioned risk factors.

Treatment of pneumothorax during pregnancy was controversial. However, recent reports and reviews suggest modern conservative treatments $(9,10)$. Treatment is generally the same as for nonpregnant patients and based on the size of pneumothorax. Admission and close observation of the patient is usually done with small pneumothorax. Pneumothorax in pregnancy can be treated expectantly provided that the size is small $(<2 \mathrm{~cm})$, patient is not dyspneic and no fetal distress is present ${ }^{(9)}$. Since pneumothorax and pneumomediastinum were relatively small in this case and the patient was at a very early stage of her pregnancy, she was managed conservatively. Ten days' supportive treatment consisting of reassurance, oxygen supplement, and analgesics were sufficient for her recovery. If mentioned conditions are not fulfilled, other treatment options are needle aspiration, needle decompression, pleurodesis, tube thoracostomy, thoracotomy and thoracoscopy for recurrent, persistent or bilateral pneumothorax ${ }^{(9)}$.

The mode of delivery after a pneumothorax is also a matter of worry. According to Tanase et al., allowing spontaneous vaginal delivery after appropriate treatment of pneumothorax during pregnancy seems safe(3). If pneumothorax is diagnosed in a term pregnancy, cesarean section under general anesthesia should be avoided because the positive pressure ventilation can lead to tension pneumothorax ${ }^{(11)}$. The mode of delivery should be selected only for obstetric indications. According to previous literature the safest approach for termination is elective assisted deliveries; such as forceps assist delivery to shorten the second stage of delivery. Even if emergent cesarean section is indicated due to obstetric considerations, it should be performed under spinal anesthesia rather than a general anesthesia $^{(10)}$. In our case, elective cesarean delivery under spinal anesthesia was performed because of cephalopelvic disproportion.

Studies describe an increased risk of recurrence both in pregnancy and during childbirth in patients with pneumothorax ${ }^{(12)}$. The risk of recurrent pneumothorax in these patients is $30-40 \%$ particularly during labor ${ }^{(13)}$. Therefore, in any future pregnancy, delivery should be strongly considered when fetal pulmonary maturity can be documented(12). Also, preconceptual counselling about this risk is vital and women must be advised about potential serious adverse outcomes. Recurrent pneumothorax during pregnancy can be treated in the same way as in non-pregnant women. Prognosis is generally good for both the mother and the baby. Thoracotomy and video-assisted thoracoscopy (VATS) have been increasingly successful as procedures for managing patients. There were no maternal or fetal complications reported in those who underwent antepartum surgical intervention ${ }^{(13)}$. No recurrence of 
pneumothorax occurred in our patient neither during pregnancy nor during cesarean section.

In summary although rare, pneumothorax should be remembered in any pregnant woman with dyspnea and chest-pain and must be confirmed radiographically to distinguish it from other diseases and conditions. Therapeutical approach is the same as in non-pregnants. Most cases resolve with supportive or just expectant management. Risk of recurrence both in pregnancy and during childbirth is increased in patients with pneumothorax. Therefore, preconceptional counselling must be given to these women.

\section{Conflict of interest}

The authors declare that they have no conflict of interest.

\section{REFERENCES}

1. Mohammadi A, Ghasemi Rad M, Afrasiabi K. Spontaneous pneumothorax in pregnancy: a case report. Tüberküloz ve Toraks Dergisi 2011;59(4):396-8.

2. Annaiah TK, Reynolds SF. Spontaneous pneumothorax-a rare complication of pregnancy. J Obstet Gynaecol 2011;31(1):80-2.

3. Tanase Y, Yamada T, Kawaryu Y, Yoshida M, Kawai S. A case of spontaneous pneumothorax during pregnancy and review of the literature. Kobe J Med Sci 2007;53(5):251-5.

4. Akcay O, Uysal A, Samancilar O, Ceylan KC, Sevinc S,
Kaya SO. An unusual emergency condition in pregnancy: pneumothorax. Case series and review of the literature. Arch Gynecol Obstet 2013;287(2):391-4.

5. Brent RL. Ionizing radiation. In: Queenan JT, Hobbins JC, eds. Protocols for high-risk pregnancies. 2nd edn. Oradell (NJ): Medical Economics Books 1987;21-31.

6. Garg R, Sanjay, Das V, Usman K, Rungta S, Prasad R. Spontaneous pneumothorax: an unusual complication of pregnancy; a case report and review of literature. Ann Thorac Med 2008;3(3):104-5.

7. Gemer O, Popescu M, Lebowits O, Segal S. Pneumomediastinum in labor. Arch Gynecol Obstet 1994;255(1):47-9.

8. Bernasko JW, Brown G, Mitchell JL, Matseoane SL. Spontaneous pneumothorax following cocaine use in pregnancy. Am J Emerg Med 1997;15(1):107.

9. MacDuff A, Arnold A, Harvey J, BTS Pleural Disease Guideline Group. Management of spontaneous pneumothorax: British Thoracic Society Pleural Disease Guideline 2010 Thorax 2010;65 Suppl 2:ii18-31

10. Lal A, Anderson G, Cowen M, Lindow S, Arnold AG. Pneumothorax and pregnancy. Chest 2007;132(3):1044-8.

11. Harris EA. Tension pneumothorax in a parturient undergoing cesarean delivery. Anesth Analg 2000;90(5):1173-4.

12. Sathiyathasan S, Jeyanthan K, Furtado G, Hamid R. Pneumothorax and pneumomediastinum in pregnancy: a case report. Obstet Gynecol Int 2009;2009:465180.

13. Jain P, Goswami K. Recurrent spontaneous pneumothorax during pregnancy: a case report. J Med Case Reports 2009; $3: 81$. 